\title{
Historical U.S. Trade Deficits
}

Brian Reinbold, Research Associate

Yi Wen, Assistant Vice President and Economist

unning a trade deficit is nothing new for the United States. Indeed, it has run a persistent trade deficit since the 1970s-but it also did throughout most of the 19th century. Figure 1 shows the U.S. goods trade balance as a percent of GDP (gross domestic product) from 1800 to 2018. From 1800-1870, the United States ran a trade deficit for all but three years and the trade balance averaged about -2.2 percent of GDP. Then from 1870-1970, it ran persistent trade surpluses that averaged about 1.1 percent of GDP. Starting in about 1970, the United States began to run trade deficits again, which have continued to this day. These shifts in the long-term U.S. trade balance appear to correspond well with U.S. industrialization in a global setting.

Historically, industrialization has three phases: (i) the first industrial revolution features labor-intensive mass production, (ii) the second industrial revolution features capital-intensive mass production, and (iii) the welfare revolution features mass consumption in a financial services-oriented welfare state. We hypothesize that industrialization leads to structural changes that cause a nation's comparative advantages to change relative to those of other nations. Since countries trade based on their comparative advantages, we would expect to see long-term changes to a country's trade as it enters a new stage of development. Therefore, the long-term trends in Figure 1 can best be understood in the context of U.S. development.

\section{U.S. trade deficits appear to follow phases of industrialization.}

As Europe, led by Great Britain, began to industrialize in the late 18th century, the United States remained primarily agrarian. U.S. industrialization began in the early 19th century, focusing on labor-intensive manufacturing such as textiles. As a latecomer to industrialization and thus playing catch-up with Europe, the United States still had to import many manufactured goods, including machinery and other capital, and relied on the exports of crude materials such as cotton. Europe could produce manufactured goods more cheaply, and the United States could not yet match Europe's prolific innovations. As a result, the United States ran large deficits in several classes of manufactured goods throughout most of the 19th century. Possibly because manufactured goods command higher profits, the U.S. surplus in raw material exports was not

Figure 1

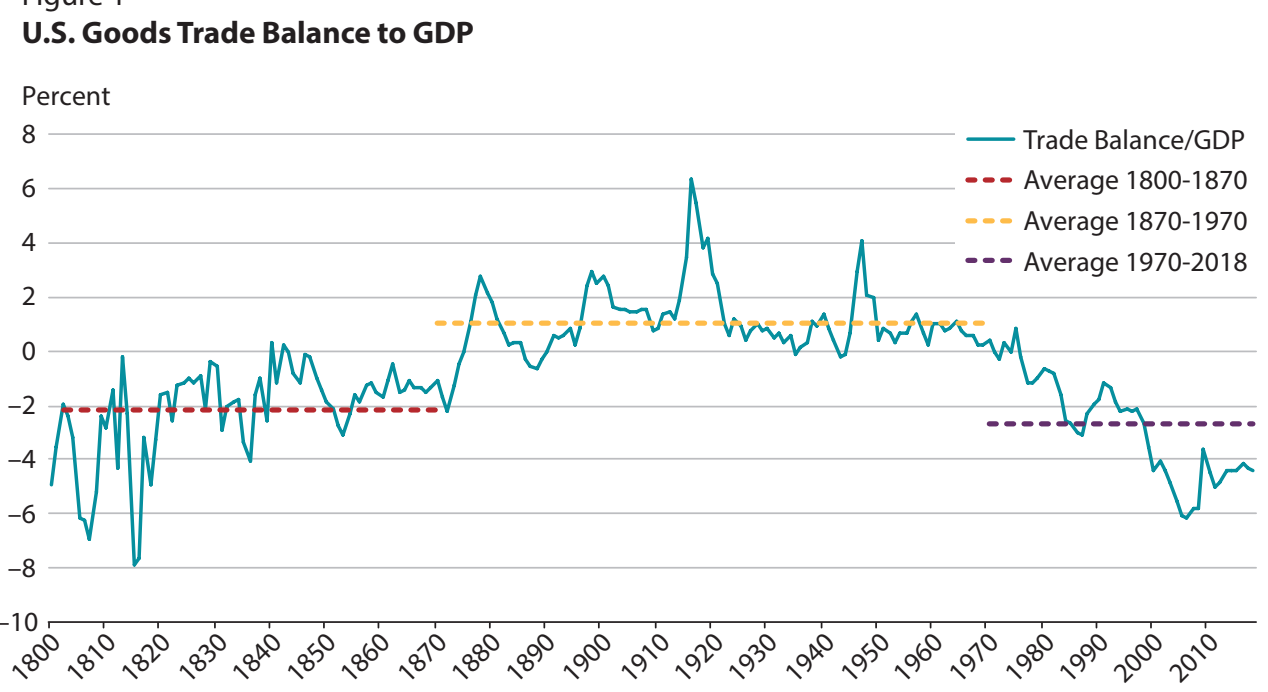

SOURCE: Bureau of Economic Analysis, World Trade Historical Database, Measuring Worth, and authors' calculations. 
Figure 2

U.S. Trade Balance to GDP: Raw Materials and Manufactured Goods

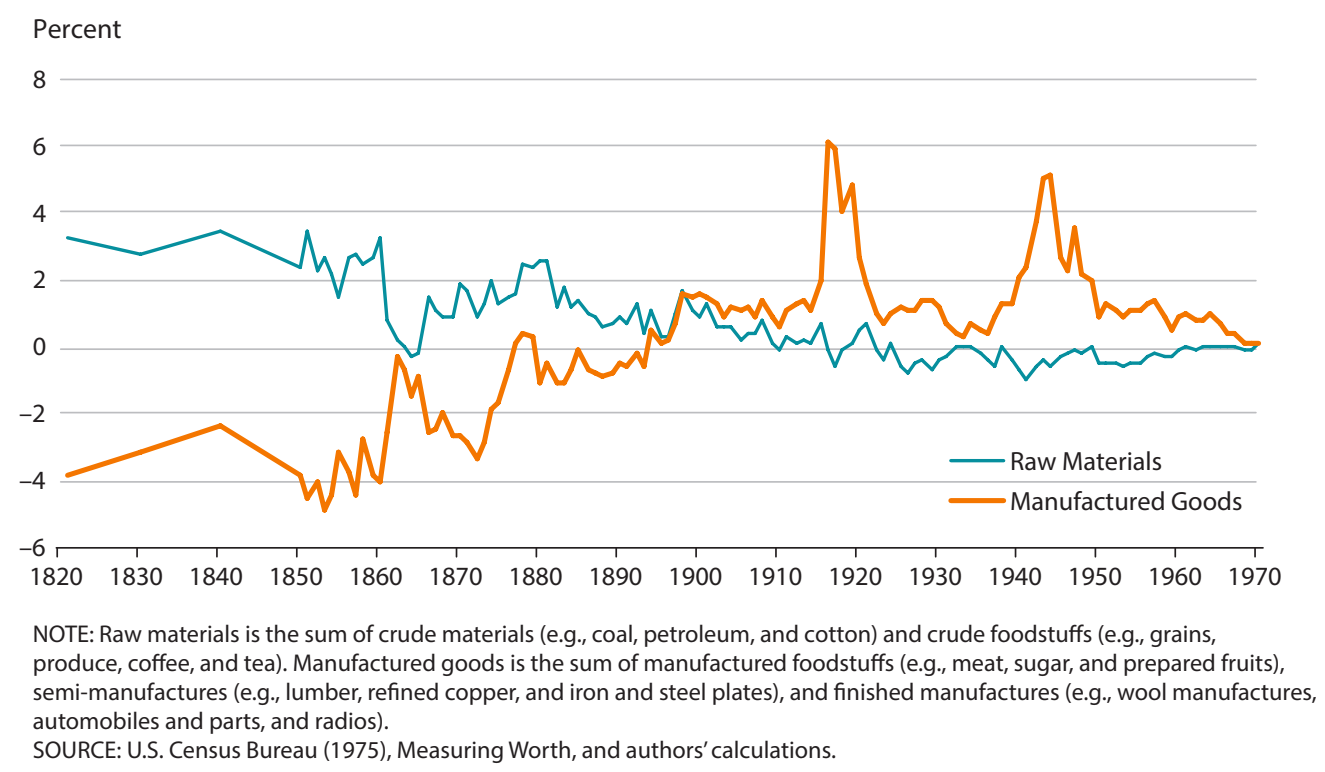

enough to overcome its deficit in manufactured goods in the early 19th century (Figure 2). However, these persistent deficits do not appear to have hobbled U.S. development.

U.S. consumers benefited from imported manufactured goods, and furthermore, the United States could import capital goods to facilitate its own industrialization. By 1870, after the Civil War, improved manufacturing methods and the proliferation of railroads propelled the United States into the second phase of industrialization, which featured capital-intensive mass production of manufactured goods and machinery. This shift corresponds with a turning point in the U.S. trade balance-from persistent trade deficits to persistent trade surpluses. Increased sophistication and maturation of U.S. manufacturing drove this change as the United States relied less on imports of manufactured goods and increased its exports of manufactured goods. By the turn of the century, the United States-now a manufacturing powerhouse-ran a full-fledged surplus in manufactured goods (see Figure 2). Instead of just following Europe's industrialization, the United States became a leading innovator. The U.S. trade surplus in manufactured goods grew, and the overall U.S. trade surplus persisted for 70 years.

Since the 1960s, the United States has shifted to the welfare stage, featuring mass consumption with financial innovations. This shift implies that the United States became able to consume more tangible goods than it pro- duced by providing financial services to the world. During the early 1970s, the U.S. trade balance experienced another inflection point-from trade surpluses to trade deficitsas U.S. financial assets became more attractive to foreign investors. Again, this shift also corresponds with a structural change in the economy as the United States entered the third stage of industrialization.

The United States ran persistent trade deficits for large parts of its history, just as it does today. Trade deficits did not inhibit U.S. development, however, and may have even facilitated industrialization as the United States could import capital goods to improve its own manufacturing during its first phase of industrialization. Not all developing countries will follow the same pattern (i.e., from trade deficit to surplus back to deficit). But it seems reasonable to expect that transitions into different stages of industrialization will cause structural changes in an economy, including changes in comparative advantages relative to other nations; and comparative advantage is what international trade is based on.

\section{Reference}

U.S. Census Bureau. "Chapter U: International Transactions and Foreign Commerce," in Bicentennial Edition: Historical Statistics of the United States. September 1975; https://www.census.gov/library/publications/1975/compendia/hist stats colonial-1970.html. 